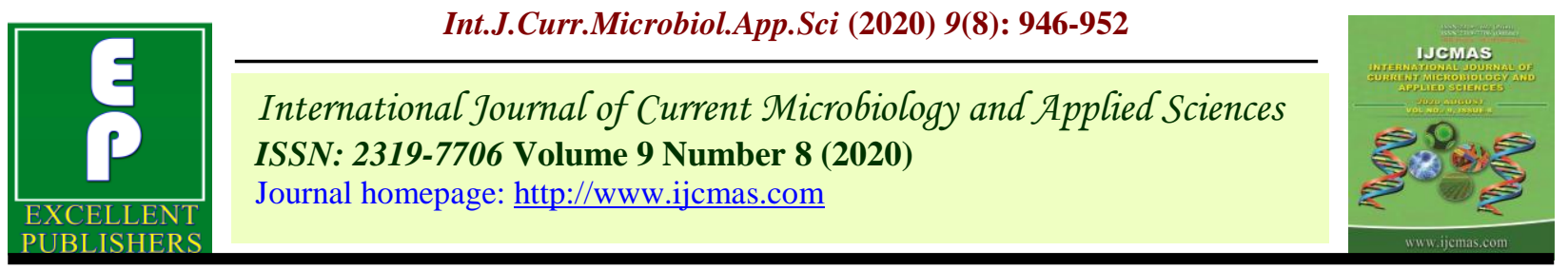

\title{
Effect of Weed Management Practices on Tomato Yield Parameters, Yield and Soil Microbial Population
}

\author{
M. Jeeva ${ }^{1 *}$, E. Somasundaram ${ }^{2}$, P. Murali Arthanari ${ }^{1}$, \\ K. Shoba Thingalmaniyan ${ }^{3}$ and K. Ganesan ${ }^{4}$ \\ ${ }^{1}$ Department of Agronomy, ${ }^{2}$ Department of Sustainable Organic Agriculture, ${ }^{3}$ Department of \\ Vegetable crops, ${ }^{4}$ Agricultural Research Station Bhavanisagar, Tamil Nadu Agricultural \\ University, Coimbatore 641 003, India \\ *Corresponding author
}

\section{A B S T R A C T}

\section{Keywords}

Organic tomato, Weed management, Microbial population, Weed compost

\section{Article Info}

Accepted:

10 July 2020 Available Online: 10 August 2020
A field experiment was carried out at farmer's field, Mudhalipalayam, Coimbatore during kharif 2019 to evaluate the effect of different weed management practices on organic tomato yield and soil microbial population. The experiment was laid out in a randomized block design with three replication and twelve treatments. Microbial count were recorded at 30, 60 and 90 DAT. The study revealed that the higher microbial population viz., fungi, bacteria and actinomycetes recorded under application of weed compost @ 5 t/ha during last ploughing + one hand weeding at 30 DAT followed by mulching with dried mango leaves 5 tonnes/ha + one hand weeding at 45 DAT and lowest was observed in unweeded check. The study also showed that mulching with dried mango leaves @ 5 tonnes/ha + one hand weeding at 45 DAT recorded higher no of fruits plant $^{-1}(26.4)$, fruit weight $(\mathrm{g})$ (79.0) and yield (77.34 tonnes ha $^{-1}$ ) and lowest was observed in unweeded check.

\section{Introduction}

Tomato (Solanum lycopersicum) is a popular vegetable belongs to Solanaceae family, which is considered as most important vegetable crop and known as poor man's orange due to its specific nutritive values. Naturally tomato receives high amount of inputs viz., inorganic fertilizers and plant protection chemicals leads to the more toxic accumulation and is consumed as horticultural maturity. Concerning the ill effects of chemical farming, now the trend have changed to organic farming and there is an emerging awareness among public on consuming organic produces.

However, organic production system is vulnerable to biotic and abiotic stress. Among biotic stress, weeds cause 45 per cent yield loss (Rao, 1993). Hence, managing the weeds during the critical period of weed competition leads to better productivity. By using organic method of weed management having the potential of controlling weeds and also increasing soil micro flora and fauna than the 
chemical herbicides. The increasing activity of micro flora and fauna activity leads to balanced soil fertility condition, biochemical transformation and also important in regulating the source and sink of mineral nutrition (Jenkinson and Ladd, 1981). In soil ecosystem, microbes functioning on different ecosystem like organic matter decomposition, nutrient cycling and terrestrial carbon cycle (Schimel. 1995). Thus, the action of microbes on soil leads to organic matter decomposition which release nutrients for the better crop production and also improves the physiochemical properties of the soil. Hence, this study was undertaken to understand the effect on organic tomato to weed management practices on microorganism's population viz., fungi, actinomycetes and bacteria.

\section{Materials and Methods}

The field experiment was conducted during kharif 2019 at farmer's field, Mudhalipalayam, Coimbatore, Tamil Nadu. The soil of the experiment field having the clay loam texture with a $\mathrm{p}^{\mathrm{H}}$ and EC of 7.8 and 0.42 , respectively. The experiment was laid out in randomised block design with twelve treatments and three replications. The treatment details include $T_{1}$ - stale seed bed technique + one hand weeding at $45 \mathrm{DAT}, \mathrm{T}_{2}$ -intercropping tomato with vegetable cowpea, $\mathrm{T}_{3}$ - intercropping tomato with marigold, $\mathrm{T}_{4}$ mulching with dried mango leaves 5 tonnes/ha + one hand weeding at $45 \mathrm{DAT}, \mathrm{T}_{5}$ - foliar spraying of lemongrass leaf extract @ $10 \%$ at $4-5$ leaf stage of weed + one hand weeding at 45 DAT, $\mathrm{T}_{6}$ - post emergence application of vinegar @10\% + one hand weeding at $45 \mathrm{DAT}, \mathrm{T}_{7}$ - multi varietal seed technique and insitu incorporation at $45 \mathrm{DAT}$, $\mathrm{T}_{8}$ - application of weed compost @ $5 \mathrm{t} / \mathrm{ha}$ during last ploughing + one hand weeding at 30 DAT, T ${ }_{9}$ - foliar spraying of cow's urine @ $10 \%$ at $4-5$ leaf stage of weed, $\mathrm{T}_{10}-$ foliar spraying of non-edible oilcake extract @ 10\% at 4-5 leaf stage of weed, $\mathrm{T}_{11}$ - weed free check, $\mathrm{T}_{12}$ - unweeded check. Serial dilution plate count and agar plate count method were used for counting the microbial colonies. The intial microbial composition of soil bacteria was $57.8 \mathrm{CFU} \times 10^{6} \mathrm{~g}^{-1}$ of soil, actinomycetes $11.7 \mathrm{CFU} \times 10^{3} \mathrm{~g}^{-1}$ of soil and fungi 22.4CFU x $10^{4} \mathrm{~g}^{-1}$ of soil.

\section{Assesment of yield parameters}

\section{Fruits per plant}

Vegetable maturity attained fruits were recorded from first to the last harvest in the five tagged plants of each treatment and the mean number of fruits per plant was calculated.

\section{Individual fruit weight}

The weight of individual fruit at each harvest was recorded from the average weight of five randomly selected plants from each plot and expressed in grams.

\section{Yield per hectare}

This parameter was calculated on the basis of recorded yield per plant multiplied with plant population per hectare and expressed in $\mathrm{tha}^{-1}$.

\section{Assessment of soil microbial population}

Soil samples from $(0-15 \mathrm{~cm})$ different treatments were collected and $10 \mathrm{~g}$ of soil (treatment wise) was mixed in $90 \mathrm{ml}$ sterilized water blank to give $10^{-1}$ dilutions. Subsequent dilutions up to $10^{-6}$ were made by transferring serially one $\mathrm{ml}$ of each dilution to nine $\mathrm{ml}$ sterilized water blanks. The population of bacteria, fungi, actinomycetes were estimated by serial dilution and plate count technique by plating on appropriate media viz., Nutrient Agar, Martins Rose Bengal Agar media and Ken knights Agar media, respectively. The 
inoculated plates were kept for incubation at $30^{\circ} \mathrm{C} \pm 1^{\circ} \mathrm{C}$ and emerged colonies were counted. The incubation time varied based on the microorganisms. The microbial population was expressed as colony forming units ( $\mathrm{CFU}$ $\mathrm{g}^{-1}$ ) of the soil as per the method suggested by Jensen (1968).

\section{Total bacteria}

Total bacteria were estimated in the $10^{-6}$ dilution by the plate count method using nutrient agar medium (Collings and Lyne, 1968).

\section{Total fungi}

Total fungi were estimated in the $10^{-4}$ dilution by the plate count method using Martins Rose Bengal agar medium (Martin, 1950).

\section{Total actinomycetes}

Total actinomycetes were estimated in the $10^{-}$

3 dilution by the plate count method using ken knights Agar medium (Ken knights, 1939).

\section{Results and Discussion}

The use of different weed management in organic tomato cultivation showed a significant effect on yield attributes, yield and microbial population. The results obtained from the study are discussed below.

\section{Yield attributes of tomato}

The data on yield attributes of tomato are presented in Table 1.

All the weed control practices significantly influenced the yield attributes of tomato compared to unweeded check. Mulching with dried mango leaves @ 5 tonnes/ha + one hand weeding at $45 \mathrm{DAT}\left(\mathrm{T}_{4}\right)$ recorded higher no of fruits plant ${ }^{-1}(26.4)$, induvial fruit weight (79.0 g) (77.34and tonnes $\mathrm{ha}^{-1}$ ) followed by post emergence application of vinegar @ 10\% + one hand weeding at 45 DAT $\left(\mathrm{T}_{6}\right)$,which recorded the no of fruits plant $^{-1}(22.7)$, fruit weight $(71.2 \mathrm{~g})$ and yield (57.85tonnes $\mathrm{ha}^{-1}$ ) and this might be due to decreasing the growth of weeds and keeping the weeds suppressed during critical growth stage. These findings are in accordance with Muhammed et al., (2015), who reported that more yield were obtained by using of organic mulches like mango leaves in okra with higher microbial population. With respect to the yield, greater influence might be on the microbial population in mulched plot that unmulched plot. Use of mango leaves as a mulch maintained almost constant increase in the microbial population (Muhammed et al., 2015). And lower no of fruits plant ${ }^{-1}(14.2)$, induvial fruit weight $(47.8 \mathrm{~g})$ and yield $\left(25.4\right.$ tonnes $\left.\mathrm{ha}^{-1}\right)$ recorded in unweeded check $\left(\mathrm{T}_{12}\right)$ due to competition for moisture, nutrients between crop and weeds.

\section{Microbial population}

The data on fungal population of the soil at different growth stage are presented in Table 2.

Application of weed compost @ 5 t/ha during last ploughing + one hand weeding at 30 $\operatorname{DAT}\left(\mathrm{T}_{8}\right)$ recorded higher population (32.6, 37.3 and $39.3 \mathrm{CFU} \times 10^{4} \mathrm{~g}^{-1}$ of the soil at 30,60 , and 90 DAT, respectively) and was followed by mulching with dried mango leaves 5 tonnes/ha + one hand weeding at 45 DAT $\left(\mathrm{T}_{4}\right)$ and foliar spraying of non-edible oilcake extract @ 10\% at 4-5 leaf stage of weed $\left(\mathrm{T}_{10}\right)$ at all the stage of observation $v i ., 30,60$ and 90 DAT respectively. The lowest population was recorded in the unweeded check $\left(\mathrm{T}_{12}\right)(21.3,24.9$ and 27.6 CFU $\times 10^{4} \mathrm{~g}^{-1}$ of the soil at 30,60 and 90 DAT respectively). 
Table.1 Effect of different non-chemical weed management practices on yield attributes in organic tomato cultivation

\begin{tabular}{|c|c|c|c|c|}
\hline \multirow{2}{*}{$\begin{array}{l}\text { T. } \\
\text { No. }\end{array}$} & \multirow[b]{2}{*}{ Treatments } & \multicolumn{3}{|c|}{ Tomato fruit yield } \\
\hline & & $\begin{array}{l}\text { No. of } \\
\text { fruits/pl } \\
\text { ant }\end{array}$ & $\begin{array}{c}\text { Individual } \\
\text { fruit } \\
\text { weight(g) }\end{array}$ & $\begin{array}{l}\text { Tomato } \\
\text { fruit yield } \\
\text { (t/ha) }\end{array}$ \\
\hline $\mathbf{T}_{1}$ & Stale seed bed technique + one hand weeding at 45 DAT & 19.70 & 64.20 & 46.84 \\
\hline $\mathbf{T}_{2}$ & Intercropping tomato with vegetable cowpea & 16.30 & 54.80 & 33.08 \\
\hline $\mathbf{T}_{3}$ & Intercropping tomato with marigold & 16.10 & 52.10 & 31.06 \\
\hline $\mathbf{T}_{4}$ & Mulching with dried mango leaves 5 tonnes/ha + one hand weeding at 45 DAT & 26.40 & 79.10 & 77.34 \\
\hline $\mathbf{T}_{5}$ & $\begin{array}{l}\text { Foliar spraying of lemongrass leaf extract @ } 10 \% \text { at } 4-5 \text { leaf stage of weed + one hand } \\
\text { weeding at } 45 \text { DAT }\end{array}$ & 20.79 & 69.40 & 53.46 \\
\hline $\mathbf{T}_{6}$ & Post emergence application of vinegar @ 10\% + one hand weeding at 45 DAT & 22.70 & 71.20 & 59.85 \\
\hline $\mathbf{T}_{7}$ & Multi varietal seed technique and insitu incorporation at 45 DAT & 19.30 & 60.80 & 43.45 \\
\hline $\mathbf{T}_{8}$ & $\begin{array}{l}\text { Application of weed compost @ } 5 \text { t/ha during last ploughing + one hand weeding at } 30 \\
\text { DAT }\end{array}$ & 18.30 & 60.30 & 40.87 \\
\hline $\mathbf{T}_{9}$ & Foliar spraying of cow's urine@10\% at 4-5 leaf stage of weed & 18.90 & 61.70 & 43.18 \\
\hline $\mathbf{T}_{10}$ & Foliar spraying of non-edible oilcake extract @ 10\% at 4-5 leaf stage of weed & 17.60 & 58.73 & 38.06 \\
\hline $\mathbf{T}_{11}$ & Weed free check & 28.30 & 82.90 & 86.89 \\
\hline $\mathbf{T}_{12}$ & Unweeded check & 14.20 & 47.80 & 25.14 \\
\hline & SEd & 1.17 & 3.12 & 2.61 \\
\hline & $\mathrm{CD}(\mathrm{P}=0.05)$ & 2.43 & 6.48 & 5.41 \\
\hline
\end{tabular}

DAT - Days after Transplanting

Table.2 Effect of different non-chemical weed management practices on fungal population (x $10^{4} \mathrm{CFU} \mathrm{g}^{-1}$ of soil) in organic tomato cultivation

\begin{tabular}{|c|c|c|c|c|}
\hline \multirow{2}{*}{$\begin{array}{l}\text { T. } \\
\text { No. }\end{array}$} & \multirow[b]{2}{*}{ Treatments } & \multicolumn{3}{|c|}{ Fungi } \\
\hline & & $\begin{array}{c}30 \\
\text { DAT }\end{array}$ & $\begin{array}{c}\text { 60 } \\
\text { DAT }\end{array}$ & $\begin{array}{c}\text { At } \\
\text { harvest }\end{array}$ \\
\hline $\mathbf{T}_{1}$ & Stale seed bed technique + one hand weeding at 45 DAT & 27.1 & 31.2 & 33.1 \\
\hline $\mathbf{T}_{2}$ & Intercropping tomato with vegetable cowpea & 25.3 & 30.8 & 33.8 \\
\hline $\mathbf{T}_{3}$ & Intercropping tomato with marigold & 24.6 & 29.7 & 34.2 \\
\hline $\mathbf{T}_{4}$ & Mulching with dried mango leaves 5 tonnes/ha + one hand weeding at 45 DAT & 31.9 & 36.2 & 38.0 \\
\hline $\mathbf{T}_{5}$ & $\begin{array}{l}\text { Foliar spraying of lemongrass leaf extract @ } 10 \% \text { at } 4-5 \text { leaf stage of weed + one hand } \\
\text { weeding at } 45 \text { DAT }\end{array}$ & 29.5 & 34.0 & 36.3 \\
\hline $\mathbf{T}_{6}$ & Post emergence application of vinegar@10\% + one hand weeding at 45 DAT & 30.1 & 33.8 & 36.9 \\
\hline $\mathbf{T}_{7}$ & Multi varietal seed technique and insitu incorporation at 45 DAT & 25.8 & 35.5 & 37.8 \\
\hline $\mathbf{T}_{8}$ & $\begin{array}{l}\text { Application of weed compost @ } 5 \mathrm{t} / \mathrm{ha} \text { during last ploughing }+ \text { one hand weeding at } 30 \\
\text { DAT }\end{array}$ & 32.6 & 37.3 & 39.3 \\
\hline $\mathbf{T}_{9}$ & Foliar spraying of cow's urine@10\% at 4-5 leaf stage of weed & 30.4 & 33.1 & 36.8 \\
\hline $\mathbf{T}_{10}$ & Foliar spraying of non-edible oilcake extract @ 10\% at 4-5 leaf stage of weed & 31.6 & 35.2 & 38.1 \\
\hline $\mathbf{T}_{11}$ & Weed free check & 26.5 & 34.8 & 36.5 \\
\hline $\mathbf{T}_{12}$ & Unweeded check & 21.3 & 24.9 & 27.6 \\
\hline & SEd & 0.98 & 0.92 & 1.08 \\
\hline & $\mathrm{CD}(\mathrm{P}=0.05)$ & 2.02 & 1.92 & 2.24 \\
\hline
\end{tabular}

DAT - Days after Transplanting 
Table.3 Effect of different non-chemical weed management practices on bacterial population (x $10^{6} \mathrm{CFU} \mathrm{g}^{-1}$ of soil) in organic tomato cultivation

\begin{tabular}{|c|c|c|c|c|}
\hline \multirow{2}{*}{$\begin{array}{l}\text { T. } \\
\text { No. }\end{array}$} & \multirow[b]{2}{*}{ Treatments } & \multicolumn{3}{|c|}{ Bacteria } \\
\hline & & $\begin{array}{c}30 \\
\text { DAT }\end{array}$ & $\begin{array}{c}\text { 60 } \\
\text { DAT }\end{array}$ & $\begin{array}{c}\text { At } \\
\text { harvest }\end{array}$ \\
\hline $\mathbf{T}_{1}$ & Stale seed bed technique + one hand weeding at 45 DAT & 58.3 & 61.7 & 70.8 \\
\hline $\mathbf{T}_{2}$ & Intercropping tomato with vegetable cowpea & 62.2 & 72.7 & 81.5 \\
\hline $\mathbf{T}_{3}$ & Intercropping tomato with marigold & 54.9 & 63.8 & 71.2 \\
\hline $\mathbf{T}_{4}$ & Mulching with dried mango leaves 5 tonnes/ha + one hand weeding at 45 DAT & 62.8 & 68.8 & 78.6 \\
\hline $\mathbf{T}_{5}$ & $\begin{array}{l}\text { Foliar sprayingof lemongrass leaf extract @ } 10 \% \text { at } 4-5 \text { leaf stage of weed + one hand } \\
\text { weeding at } 45 \text { DAT }\end{array}$ & 59.3 & 65.2 & 73.8 \\
\hline $\mathbf{T}_{6}$ & Post emergence application of vinegar @ 10\% + one hand weeding at 45 DAT & 60.0 & 68.4 & 77.1 \\
\hline $\mathbf{T}_{7}$ & Multi varietal seed technique and insitu incorporation at 45 DAT & 55.8 & 71.8 & 80.6 \\
\hline $\mathbf{T}_{8}$ & $\begin{array}{l}\text { Application of weed compost @ } 5 \text { t/ha during last ploughing + one hand weeding at } 30 \\
\text { DAT }\end{array}$ & 64.3 & 73.2 & 82.7 \\
\hline $\mathbf{T}_{9}$ & Foliar sprayingof cow's urine@10\% at 4-5 leaf stage of weed & 61.9 & 69.2 & 79.4 \\
\hline $\mathbf{T}_{10}$ & Foliar sprayingof non-edible oilcake extract @ $10 \%$ at $4-5$ leaf stage of weed & 60.3 & 66.2 & 75.6 \\
\hline $\mathbf{T}_{11}$ & Weed free check & 56.1 & 64.0 & 74.6 \\
\hline $\mathbf{T}_{12}$ & Unweeded check & 51.7 & 57.7 & 59.6 \\
\hline & SEd & 1.70 & 1.66 & 2.00 \\
\hline & $\mathrm{CD}(\mathrm{P}=0.05)$ & 3.53 & 3.44 & 4.16 \\
\hline
\end{tabular}

DAT - Days after Transplanting

Table.4 Effect of different non-chemical weed management practices on actinomycetes population (x $10^{3} \mathrm{CFU} \mathrm{g}^{-1}$ of soil) in organic tomato cultivation

\begin{tabular}{|c|c|c|c|c|}
\hline \multirow{2}{*}{$\begin{array}{l}\text { T. } \\
\text { No. }\end{array}$} & \multirow[b]{2}{*}{ Treatments } & \multicolumn{3}{|c|}{ Actinomycetes } \\
\hline & & $\begin{array}{c}30 \\
\text { DAT }\end{array}$ & 60 DAT & $\begin{array}{c}\text { At } \\
\text { harvest }\end{array}$ \\
\hline $\mathbf{T}_{1}$ & Stale seed bed technique + one hand weeding at 45 DAT & 11.6 & 14.2 & 16.1 \\
\hline $\mathbf{T}_{2}$ & Intercropping tomato with vegetable cowpea & 11.7 & 13.6 & 16.8 \\
\hline $\mathbf{T}_{3}$ & Intercropping tomato with marigold & 11.4 & 13.1 & 15.3 \\
\hline $\mathbf{T}_{4}$ & Mulching with dried mango leaves 5 tonnes/ha + one hand weeding at 45 DAT & 14.0 & 16.1 & 18.2 \\
\hline $\mathbf{T}_{5}$ & $\begin{array}{l}\text { Foliar spraying of lemongrass leaf extract @ } 10 \% \text { at } 4-5 \text { leaf stage of weed + one hand } \\
\text { weeding at } 45 \text { DAT }\end{array}$ & 12.1 & 13.8 & 15.9 \\
\hline $\mathbf{T}_{6}$ & Post emergence application of vinegar @ 10\% + one hand weeding at 45 DAT & 12.6 & 15.1 & 17.8 \\
\hline $\mathbf{T}_{7}$ & Multi varietal seed technique and insitu incorporation at 45 DAT & 11.7 & 16.1 & 18.4 \\
\hline $\mathbf{T}_{8}$ & $\begin{array}{l}\text { Application of weed compost @ } 5 \text { t/ha during last ploughing + one hand weeding at } \\
30 \text { DAT }\end{array}$ & 15.4 & 17.4 & 19.7 \\
\hline $\mathbf{T}_{9}$ & Foliar spraying of cow’s urine@10\% at 4-5 leaf stage of weed & 12.8 & 14.2 & 16.1 \\
\hline $\mathbf{T}_{10}$ & Foliar spraying of non-edible oilcake extract @ $10 \%$ at $4-5$ leaf stage of weed & 13.7 & 15.0 & 17.1 \\
\hline $\mathbf{T}_{11}$ & Weed free check & 11.8 & 13.6 & 14.5 \\
\hline $\mathbf{T}_{12}$ & Unweeded check & 9.8 & 10.4 & 11.6 \\
\hline & SEd & 0.46 & 0.44 & 0.47 \\
\hline & $\mathrm{CD}(\mathrm{P}=0.05)$ & 0.96 & 0.92 & 0.99 \\
\hline
\end{tabular}

DAT - Days After Transplanting 
The data on bacterial population of the soil at different growth stage are presented in Table 3.

Application of weed compost @ 5 t/ha during last ploughing + one hand weeding at 30 $\operatorname{DAT}\left(\mathrm{T}_{8}\right)$ was recorded higher bacterial population $\left(64.3,73.2\right.$ and $82.7 \mathrm{CFU} \times 10^{6} \mathrm{~g}^{-1}$ of the soil at 30,60, and 90 DAT, respectively) and was comparable with intercropping tomato with vegetable cowpea $\left(\mathrm{T}_{2}\right)$ and foliar spraying of non-edible oilcake extract @ 10\% at 4-5 leaf stage of weed $\left(\mathrm{T}_{10}\right)$ at 30, 60 and 90 DAT. At 90 DAT, the bacterial population of multi varietal seed technique and insitu incorporation at 45 DAT $\left(\mathrm{T}_{7}\right)$ (80.6 CFU x $10^{6} \mathrm{~g}^{-1}$ of the soil) which was on par with application of weed compost @ $5 \mathrm{t} / \mathrm{ha}$ during last ploughing + one hand weeding at 30 DAT $\left(\mathrm{T}_{8}\right)\left(82.7 \mathrm{CFU} \times 10^{6} \mathrm{~g}^{-1}\right.$ of the soil). The lowest number of population was recorded in unweeded check $\left(\mathrm{T}_{12}\right)(51.7$, 57.7 and $59.6 \mathrm{CFU} \times 10^{6} \mathrm{~g}^{-1}$ of the soil at 30 , 60 and 90 DAT, respectively).

The data on actinomycetes population of the soil at different growth stage are presented in Table 4.

At all the stages of observation viz., 30,60 and 90 DAT, a higher actinomycetes population were recorded in Application of weed compost@ 5 t/ha during last ploughing + one hand weeding at $30 \mathrm{DAT}\left(\mathrm{T}_{8}\right)(15.4,17.7$ and 19.7 CFU x $10^{3} \mathrm{~g}^{-1}$ of the soil at 30,60 , and 90 DAT, respectively) followed by mulching with dried mango leaves @ 5 tonnes/ha + one hand weeding at 45 DAT $\left(\mathrm{T}_{4}\right)$ and foliar spraying of non-edible oilcake extract @ 10\% at 4-5 leaf stage of weed $\left(\mathrm{T}_{10}\right)$. And the lowest number of recorded in unweeded check $\left(\mathrm{T}_{12}\right)$ $\left(9.8,10.4\right.$ and $11.6 \mathrm{CFU} \times 10^{3} \mathrm{~g}^{-1}$ of the soil at 30, 60 and 90 DAT, respectively).

Use of weed compost increased the bacterial, fungal and actinomycetes population soil.
These finding is in agreement with the outcome that application of organic matter supported larger and diverse population of microorganisms (Sathyanarayana, 2006). At later stage the live mulching with multivarietal crops $\left(\mathrm{T}_{4}\right)$ increased soil bacterial population. This might be due to higher organic carbon content of the soil and this would have helped to increase the soil micro flora. According to Rathod (2017) weed incorporation in soil helped to boost microbial population in the soil.

Muhammed et al., (2015) reported that organic matter decomposition increased the actinomycetes population at the end of the crop growth stage. Due to the organic matter decomposition resulted in the carbon availability which might be increased the actinomycetes population (Pal et al., 2013). Use of organic mulches increased the fungal population in the wheat as reported by Yanbing et al., (2008).

The organic mulch added organic matter (3-5 tonnes/ha), which might have stimulated the soil micro flora that performs a role in the nutrients cycle as well as increased the biological activity in the soil (Bhardwaj, 2013). The lowest microbial population was recorded in the unweeded check $\left(\mathrm{T}_{12}\right)$ due to non availability of nutrients these findings are supported by Rathod (2017) who reported that non availability of nutrients and organic matter which may resulted in the unfavourable condition for the microbial growth.

From this study, the higher microbial population viz., bacteria, fungi and actinomycetes population were recorded in application of weed compost @ 5 t/ha during last ploughing + one hand weeding at $30 \mathrm{DAT}$ $\left(\mathrm{T}_{8}\right)$ might be application of organic matter supported larger and diverse population of microorganisms and lower microbial 
population were recorded in unweeded check $\left(\mathrm{T}_{12}\right)$ due to competition for moisture, nutrients between crop and weeds.

\section{References}

Bhardwaj, R.L. 2013. Effect of mulching on crop production under rainfed condition - A Review. Agri. Rev., 34(3): 188-197.

Collings, C.H. and Lyne, M.P. 1968. Microbiological methods, 5th Edition, Butter Worth, London.

Jenkinson, D.S. and Ladd, J.N. 1981. Microbial Biomass in Soil: Measurement and Turnover. In: Soil Biochemistry, Paul, E.A. and J.N. Ladd (Eds.). Marcel Dekker, New York, USA., pp: 415-471.

Jensen, V. 1968. The plate count method. In: the ecology of soil bacteria: An international symposium (Eds.) T.R.G. Gray and D. Parkinsons, Liverpool University Press, Liverpool: pp. 158170.

Kenknight, G. and Muncie, J.H. 1939. Isolation of phytopathogenic actinomycetes. hytopath., 29: 10001001.

Martin, J.P. 1950. Use of acid, rose Bengal and streptomycin in the plate method for estimating soil fungi. Soil Sci., 69: 215-233.

Muhammed, U. F. B., Sindhu, P. V., Gopal, K. S., \& Thomas, C. G. (2015).
Influence of mulches on rhizosphere microflora, yield and weed competition in okra [Abelmoschus esculentus (L.) Moench]. Journal of Tropical Agriculture, 53(1), 70-74.

Pal, D., Bera, S. and Ghosh, R.K. 2013. Influenceof herbicides on soyabean yield, soil microfloraand urease enzyme activity. Indian J. Weed Sci.,45(1): 34-38.

Rao, V.S. 1993. Principles of weed sciences. Oxford and IBH publishing Co. New Delhi., p. 23-42.

Rathod, B.G.S. and Somasundaram, E., 2017. Effect of Organic Rice to Weed Management Practices on Yield Parameters and Microbial Population Grown under Lowland Condition. Int. J. Curr. Microbiol. App. Sci, 6(7), pp.2154-2162.

Satyanarayana, A. 2006. System of rice intensification: An innovative method for sustainable rice production. In: Abstracts of National Symposium on System of Rice Intensification (SRI): Present status and future prospects, November 17-18. 18-20pp.

Schimel, D.S. 1995. Terrestrial ecosystem and carbon cycle, Global Change Biol., 1:77- 91

YanBing, L., QuanHong, X. and Xia, Y. 2008.Effect of mulching mode and wheat root onsoilmicrobial flora. Chinese J. Eco Agric., 16(6):1389-139

\section{How to cite this article:}

Jeeva, M., E. Somasundaram, P. Murali Arthanari, K. Shoba Thingalmaniyan and Ganesan, K. 2020. Effect of Weed Management Practices on Tomato Yield Parameters, Yield and Soil Microbial Population. Int.J.Curr.Microbiol.App.Sci. 9(08): 946-952. doi: https://doi.org/10.20546/ijcmas.2020.908.102 